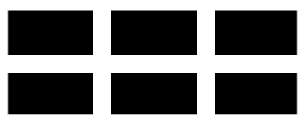

The WiLliam DAVIDSON Institute AT THE UNIVERSITY OF MICHIGAN BUSINESS SCHOOL

\title{
IMF-Related Announcements, Fundamentals, and Creditor Moral Hazard: A Case Study of Indonesia
}

\author{
By: Ayşe Y. Evrensel and Ali M. Kutan
}

William Davidson Institute Working Paper Number 680

May 2004 


\title{
IMF-Related Announcements, Fundamentals, and Creditor Moral Hazard:
}

\section{A Case Study of Indonesia}

\author{
Ayşe Y. Evrensel \\ Portland State University
}

and

\begin{abstract}
Ali M. Kutan
Southern Illinois University Edwardsville; The Emerging Markets Group, London; and The William Davidson Institute, Michigan
\end{abstract}

March 2004

JEL classification: F32, F33, F34, G15

Keywords: Moral Hazard, the IMF, Asian crisis, Financial markets

\begin{abstract}
Previous tests of creditor moral hazard cannot distinguish between two types of investor behavior: expectations of implicit guarantees or better future economic fundamentals due to a prospective IMF program. The novelty of our approach lies in the inclusion of the forward foreign exchange rate in the empirical tests of creditor moral hazard, which reflects investors' expectations about the country's future fundamentals and allows us to separate the effects of fundamentals from those of moral hazard. Using Indonesian financial markets as a case study, we first conduct tests of creditor moral hazard in the Indonesian bond and stock markets. Then, we use the forward exchange rate to confirm the interpretation of the bond and stock market results. Our results show that IMF-program related news, especially, the announcement of program negotiations, brings about higher stock returns and lower bond spreads, even though the bath sells at a forward discount on the same day. These results suggest creditor moral hazard in the Indonesian bond and equity markets.
\end{abstract}

We thank Myles Wallace for his comments on an earlier version of this paper. All errors are ours. 


\section{Introduction}

This paper investigates the possibility of creditor moral hazard in bond and stock markets by examining the changes in sovereign bond spreads, stock market and financial sector returns, and forward exchange rates, in response IMF-related news in Indonesia during the East Asian crisis. Several observers have suggested that the Fund-support to East Asian crisis countries during the crisis may have provided additional implicit guarantees to investors, which would motivate them to take excessive risks (Edwards, 1998; Eichengreen, 2000; Feldstein, 1998; Friedman, 1998; Schultz et al., 1998; Schwartz, 1998). This kind of behavior is defined as the creditor moral hazard (Sarno and Taylor, 1999; Evrensel and Kutan, 2004a,b, and c).

Recent papers on creditor moral hazard focus on different financial markets: sovereign bond markets (Kamin and Kleist, 1999; Zhang, 1999; Lane and Phillips, 2000; Tillmann, 2001; Dell'Ariccia, Schnabel, and Zettelmeyer, 2002; Evrensel and Kutan, 2004a), stock markets (Sarno and Taylor, 1999; Evrensel and Kutan, 2004b), and financial sector stocks (Evrensel and Kutan, 2004c). ${ }^{1}$ In the absence of improved fundamentals, recent studies interpret declining bond spreads and increasing stock market and financial sector returns as a sign of creditor moral hazard. However, even though it is considerably easier to estimate the changes in financial markets due to IMF-related news, the current research recognizes the difficulty of estimating investors' expectations regarding the relevant country's current and future fundamentals. Besides current fundamentals, investors also care about future fundamentals. When testing for creditor moral hazard, it is therefore important to capture investor expectations about future fundamentals in response to IMF-program news.

The novelty of this paper lies in the inclusion of a forward-looking financial market instrument to capture investor expectations regarding the country's future fundamentals. This paper examines the forward foreign exchange market as well to better interpret investors' response in stock and bond markets to IMF-program news. We use one-month forward exchange rate for the Indonesian baht to infer whether investors are trading the Indonesian currency at a forward discount or a premium on an IMF-related announcement date. Then we compare the evidence obtained from the forward exchange rate with the changes in stock returns and bond

\footnotetext{
${ }^{1}$ See Evrensel and Kutan (2004a and b) for a review of papers on creditor moral hazard in bond and stock markets respectively.
} 
spreads. A forward discount, when combined with the evidence of higher stock returns and declining bond spreads, would suggest creditor moral hazard.

At this point, we want to discuss the characteristics of relevant financial markets used in this paper. For the bond market, we use a sovereign, dollar-denominated bond. ${ }^{2}$ In the presence of creditor moral hazard, we hypothesize that investors would include more of these debt instruments in their portfolio, if IMF programs signaled implicit guarantees on their (high) returns. Even if a country defaults on its debt, some portion of its debt payments may be recovered. We assume that, everything else constant, as the probability of IMF-support increases, the spread on publicly guaranteed bonds declines. The negative relationship between the probability of an IMF-support and spreads may imply creditor moral hazard, because the IMFsupport provides the program country with funds part of which may be used by the recipient county to make payments to the holders of its sovereign bonds. ${ }^{3}$

Even though bond markets have attracted most of the attention with respect to the creditor moral hazard research, stock markets have also been receiving attention. As in the bond market, the investigation of creditor moral hazard in stock markets requires a framework in which creditor moral hazard takes place. Sarno and Taylor (1999) offer the very first tests of creditor moral hazard in equity markets, which argues that the high degree of portfolio flow reversibility combined with stock market bubbles is consistent with the moral hazard interpretation of the East Asian crisis. Based on Sarno and Taylor (1999), Evrensel and Kutan (2004b) construct a framework that contains various combinations of domestic implicit guarantees and stock market bubbles. They show that, in the presence of creditor moral hazard, domestic implicit guarantees or their combination with stock market bubbles are expected to increase stock returns. They find evidence of creditor moral hazard, but its duration is very short: creditor moral hazard, if exits, tends to last only for a few days.

Financial sector represents an interesting subsection of stock markets for two reasons. First, many observers have emphasized the vulnerabilities of the financial sector as the primary source of the East Asian crisis (among others, Krugman, 1998; Stiglitz, 1999). In fact, they have

\footnotetext{
${ }^{2}$ It can be argued that defaulting on its sovereign bonds would be damaging to a country's creditworthiness, especially when the country is currently under an IMF program and trying to signal stability and credibility. Because instruments denominated in domestic currencies are subject to exchange rate risk, we use a dollar-denominated sovereign bond.

${ }^{3}$ See Evrensel \& Kutan (2004a) for the assumptions regarding investor behavior and the formal derivation of the relationship between IMF programs and expected recovery payments.
} 
argued that the financial sectors of the crisis countries seriously suffered from adverse selection before the crisis and the extension of the IMF support, which implies that financial intermediaries or their owners were protected by implicit or explicit government guarantees against losses (Krugman, 1998; McKinnon and Pill, 1997). Second, IMF funds mainly increase the liquidity of the program country, particularly the liquidity of the financial sector. Therefore, changes in financial sector returns due to IMF-related news (such as announcements of program negotiations and approval) may reflect investors' expectations regarding the future performance of this sector due to an IMF program and the program's credibility. We expect that, in the presence of domestic implicit guarantees and non-credible IMF programs, financial sector returns should increase. 4

The paper is organized as follows. Section 2 summarizes the results of the GARCH estimations using the following three financial markets as dependent variables: bonds spreads, stock market and financial sector returns, and discount or premium in the forward exchange rate market. Section 3 provides concluding remarks.

\section{Empirical Analysis}

We use daily data on bond spreads, stock market and financial sector returns, and forward exchange rates..$^{5}$ The Indonesian spreads and US corporate bond spreads are expressed in percentage. Other variables such as the spot and forward exchange rates, reserves, stock market and financial sector returns are also computed as percentage changes in these variables, using the log-differenced series, multiplied by 100. All data are obtained Datastream, except the forward rate data, which are supplied by the Bank of Indonesia. The lack of available data on longer-term forward contracts forces us to use 1-month forward exchange rate data.

We include various IMF program dummies in our estimations. There are two announcement dummies (announcement of program negotiations and approval) and a window variable. Dummy variables take a value of 1 on the day when negotiations begin ("negotiations" in Table 2 and on the day when program approval is announced ("approval" in Table 2),

\footnotetext{
${ }^{4}$ See Evrensel and Kutan (2004c) for a detailed discussion of the framework in which creditor moral hazard occurs in the financial sector.

${ }^{5}$ The Indonesian sovereign bond used in estimations has the following characteristics regarding the issue year, the interest rate, and the maturity date, respectively: 1996, 7 3/4 percent, 08/01/06.
} 
respectively. We use the variable "window" to capture the uncertainty about the outcome of negotiations until the program announcement. This dummy variable takes a value of 1 from the day after the negotiations announcement until the day before the program announcement. Finally, the duration dummy takes the value of 1 during the IMF program and zero otherwise. Table 1 reports the dates associated with the announcements and the duration of programs.

Regarding our method of estimation, we use GARCH models to account for the timevarying volatility displayed in daily financial data. We experimented with standard GARCH as well as asymmetric threshold and exponential GARCH models. We found that the standard $\operatorname{GARCH}(1,1)$ fits the data much better than the asymmetric models. In all estimations, we use this model with Bollerslev-Wooldridge robust standard errors. Table 2 summarizes the $\operatorname{GARCH}(1,1)$ estimations of bond spreads, stock market and financial sector returns, and forward discount/premium in the exchange rate. In the following, we only report the statistically significant results, unless indicated otherwise.

First, we report the results with respect to sequential creditor moral hazard, where we look at the performance in Indonesia's financial markets on the days of IMF-related announcements in Thailand. Generally speaking, these announcements are associated with increased spreads, declining stock markets and financial sector returns, and expected devaluation in Indonesia. Even though most coefficients indicate either less than 1 percent or about 1 percent change in the performance of various financial markets, the declines in financial sector returns during the Thai-window and on the day of the Thai-program approval are 2.13 percent and 4.84 percent, respectively. The results suggest that IMF-related announcements about Thailand adversely affected Indonesia's financial markets. Therefore, we conclude that there is no evidence of sequential creditor moral hazard in Indonesia due to IMF-related announcements about Thailand.

With respect to Indonesia's own IMF-related announcements, on the day of the negotiation announcement, we observe declining spreads and increasing stock market and financial sector returns, which could be interpreted as expected improved fundamentals due to a prospective IMF program. Especially, the increase in financial sector returns was quite high, over 8 percent. However, the forward exchange rate was selling at a discount on this day (3.13 percent), which indicates expected devaluation of the Indonesian currency in a month. The results imply that, even though investors reacted favorably to the announcement of negotiations 
in bond and stock markets, investors in foreign exchange markets expected devaluation in the future. Therefore, the results obtained from the bond and stock markets are consistent with the moral hazard interpretation of investor behavior. During the window, the performance of bond and stock markets worsened. Even though the increase in spreads was rather small (.09 percent), the decline in stock market returns was over 2 percent. We conclude that the results regarding the window period do not imply creditor moral hazard.

On the day of the program approval, spreads declined (.55 percent) and financial sector returns increased (.49 percent), which implies a positive investor response to program approval. Program approval may have had some surprise components in it with respect to the size and the conditions attached to the program. However, the surprise must have been rather small, because the changes in spreads and financial sector returns indicated about a half of a percent change. While the decline in spreads is associated with the buying activity of Indonesia sovereign bonds, the decline in financial sector returns implies that some investors sold their stocks. Therefore, on the day of the program approval, financial markets send contradictory signals. Forward exchange rate discount was 1.86 percent, indicating expectations of depreciation. Therefore, the result associated with the bond market is consistent with creditor moral hazard.

During the implementation of the program (duration), we observe declining financial sector returns (.25 percent) and marginally increasing forward exchange rate (.09 percent). The results associated with the variance equation indicate that there are significant $\mathrm{ARCH}$ and GARCH effects, and, therefore, time-varying volatility, except for the bond market, in which only the GARCH(1) term is significant. Additionally, volatility in financial markets increased during the program period in Indonesia. We did not include other IMF-related news in the conditional variance due to convergence problems in estimations. However, this should not affect the inferences because moral hazard effects are reflected in the mean equation.

\section{Conclusion}

This paper addresses a particular problem in the analysis of creditor moral hazard associated with IMF-support, which is the possibility to interpret an outcome as creditor moral hazard, even though the outcome may have been produced by expected improved fundamentals. To avoid this problem, we support our results obtained from the bond and stock markets by using the forward foreign exchange market as a control variable. We compare our GARCH estimations 
of changes in bond spreads and stock market and financial sector returns due to IMF-related announcements with the changes in forward foreign exchange rates.

Our results indicate that the Thai crisis that took place before the Indonesian crisis adversely affected the Indonesian financial markets. On the days of the IMF-related announcements in Thailand, Indonesia's bond, stock, and forward foreign exchange markets performed badly, as manifested in increasing bond spreads, declining stock market and financial sector returns, and expected depreciation of the currency, which is not consistent with the sequential creditor moral hazard. However, Indonesia's own IMF-related news, especially the announcement of program negotiation, is associated with robust performances in bond and stock markets, while the forward foreign exchange market indicates the depreciation of the currency in a month.

Our paper constitutes the first attempt to control the bond and stock market results regarding creditor moral hazard by using an alternative, forward-looking market. Future research should be aimed to develop better devices to distinguish between investor behavior that implies creditor moral hazard and investor behavior that implies no moral hazard. 


\section{REFERENCES}

Dell'Ariccia, G., Schnabel, I., Zettelmeyer, J. 2002. Moral Hazard and International Crisis Lending: A Test. International Monetary Fund, Working Paper \# 181.

Edwards, S. 1998. Abolish the IMF. Financial Times, November 13.

Eichengreen, B. 2000. Can the Moral Hazard Caused by IMF Bailouts be Reduced? Geneva Reports on the World Economy Special Report 1 (September), Center for Economic Policy Research.

Evrensel, A.Y., Kutan, A.M. 2004a. The IMF and Creditor Moral Hazard in Sovereign Bond Markets: A Critical Review and New Evidence. WDI Working Paper.

Evrensel, A.Y., Kutan, A.M. 2004b. Creditor Moral Hazard in Equity Markets: A Theoretical Framework and Evidence from Indonesia and Korea. WDI Working Paper.

Evrensel, A.Y., Kutan, A.M. 2004c. Financial Sector Returns and Creditor Moral Hazard: Evidence from Indonesia, Korea, and Thailand. WDI Working Paper.

Feldstein, M. 1998. Refocusing the IMF. Foreign Affairs 77, 20-33.

Friedman, M. 1998. Markets to the Rescue. Wall Street Journal, October 13.

Kamin, S.B., Kleist, K. 1999. The Evolution and Determinants of Emerging Market Credit Spreads in the 1990s. BIS Working Papers, No. 68.

Krugman, P. 1998. What Happened to Asia? Manuscript. MIT.

Lane, T., Phillips, S. 2000. Does IMF Financing Result in Moral Hazard? IMF Working Paper, No. 168. 
McKinnon, R., Pill, H. 1996. Credible liberalizations and international capital flows: the overborrowing syndrome. In: Ito, T., A.O. Krueger, eds., Financial Deregulation and Integration in East Asia, Chicago: Chicago University Press.

Sarno, L., Taylor, M.P. 1999. Moral Hazard, Asset Price Bubbles, Capital Flows, and the East Asian crisis: The First Tests. Journal of International Money and Finance 18, 637-657.

Schultz, G., Simon, W.E., Wriston, W.B. 1998. Who Needs the IMF? Wall Street Journal, February 3.

Schwartz, A.J. 1998. Time to Terminate the ESF and the IMF. Cato Institute Policy Briefing No.48, August 26. Washington, D.C.: Cato Institute.

Tillmann, P. 2001. Switching Risk-Perception on Bond Markets: Does IMF Lending Induce Moral Hazard? University of Cologne. Working paper.

Zhang, X.A. 1999. Testing for Moral Hazard in Emerging Markets Lending. Institute for International Finance, Research Papers, No.99-1. 
Table 1: Dates associated with IMF-related news and program duration in Indonesia ${ }^{1}$

\begin{tabular}{|l|c|}
\hline \multicolumn{2}{|l|}{ Announcements associated with IMF programs ${ }^{2}$} \\
\hline Start of negotiations & $10 / 08 / 97$ \\
\hline Program approval & $11 / 05 / 97$ \\
\hline Program duration ${ }^{3}$ \\
\hline Effective date & $11 / 05 / 97$ \\
\hline Expiration date & $11 / 04 / 00$ \\
\hline
\end{tabular}

${ }^{1}$ The term "program" implies standby arrangements.

${ }^{2}$ Dates associated with IMF-related announcements are based on Lane and Phillips (2000).

${ }^{3}$ Annual Report of the IMF in 1998 and 1999 provides the duration information. Effective and expiration dates imply the start and the end of a program respectively. 
Table 2: GARCH estimations of sovereign bond spreads, stock market and financial sector returns, and forward exchange rates in Indonesia

\begin{tabular}{|c|c|c|c|c|}
\hline & $\begin{array}{c}\text { Sovereign bonds } \\
\text { spreads }\end{array}$ & $\begin{array}{l}\text { Stock market } \\
\text { returns }\end{array}$ & $\begin{array}{c}\text { Financial sector } \\
\text { returns }\end{array}$ & $\begin{array}{c}\text { Forward } \\
\text { exchange rate }\end{array}$ \\
\hline Constant & $\begin{array}{l}-.0136 \\
(.0466)^{1}\end{array}$ & $\begin{array}{c}.0419 \\
(.0416)\end{array}$ & $\begin{array}{c}.0399 \\
(.2636)\end{array}$ & $\begin{array}{l}0.0946 \\
(.0001)\end{array}$ \\
\hline $\begin{array}{l}\text { US corporate } \\
\text { spreads }\end{array}$ & $\begin{array}{l}1.4252 \\
(.0000)\end{array}$ & & & \\
\hline $\begin{array}{l}\text { Dependent variable } \\
(-1)\end{array}$ & & $\begin{array}{c}.1687 \\
(.0000)\end{array}$ & $\begin{array}{l}.0637 \\
(.0046)\end{array}$ & $\begin{array}{l}0.3093 \\
(.0000)\end{array}$ \\
\hline $\begin{array}{l}\text { Exchange rate } \\
(-1)\end{array}$ & $\begin{array}{l}.0115 \\
(.0463)\end{array}$ & & & \\
\hline $\begin{array}{l}\text { Stock returns } \\
(-1)\end{array}$ & $\begin{array}{l}.0056 \\
(.1524)\end{array}$ & & & \\
\hline $\begin{array}{l}\text { Thailand } \\
\text { negotiations }\end{array}$ & $\begin{array}{l}.0059 \\
(.6759)\end{array}$ & $\begin{array}{l}-.6064 \\
(.0000)\end{array}$ & $\begin{array}{l}-.2339 \\
(.0003)\end{array}$ & $\begin{array}{l}-0.2747 \\
(.7072)\end{array}$ \\
\hline $\begin{array}{l}\text { Thailand } \\
\text { Window }\end{array}$ & $\begin{array}{l}.0142 \\
(.5305)\end{array}$ & $\begin{array}{l}-1.2013 \\
(.0439)\end{array}$ & $\begin{array}{l}-2.1288 \\
(.0048)\end{array}$ & $\begin{array}{l}1.1156 \\
(.0027)\end{array}$ \\
\hline $\begin{array}{l}\text { Thailand } \\
\text { Approval }\end{array}$ & $\begin{array}{l}.0768 \\
(.0188)\end{array}$ & $\begin{array}{l}-1.2477 \\
(.6821)\end{array}$ & $\begin{array}{l}-4.8406 \\
(.4039)\end{array}$ & $\begin{array}{l}1.0303 \\
(.5844)\end{array}$ \\
\hline $\begin{array}{l}\text { Indonesia } \\
\text { negotiations }\end{array}$ & $\begin{array}{l}-.0807 \\
(.0000)\end{array}$ & $\begin{array}{l}1.5643 \\
(.0000)\end{array}$ & $\begin{array}{l}8.0618 \\
(.0889)\end{array}$ & $\begin{array}{l}3.1339 \\
(.0000)\end{array}$ \\
\hline $\begin{array}{l}\text { Indonesia } \\
\text { Window }\end{array}$ & $\begin{array}{l}.0991 \\
(.0925)\end{array}$ & $\begin{array}{l}-2.1221 \\
(.0971)\end{array}$ & $\begin{array}{l}-.9667 \\
(.4511)\end{array}$ & $\begin{array}{l}-0.1636 \\
(.4226)\end{array}$ \\
\hline $\begin{array}{l}\text { Indonesia } \\
\text { approval }\end{array}$ & $\begin{array}{l}-.5453 \\
(.0000)\end{array}$ & $\begin{array}{l}.2337 \\
(.1925)\end{array}$ & $\begin{array}{l}.4846 \\
(.0001)\end{array}$ & $\begin{array}{l}1.8637 \\
(.0000)\end{array}$ \\
\hline $\begin{array}{l}\text { Indonesia } \\
\text { program duration }\end{array}$ & $\begin{array}{l}-.0042 \\
(.7747) \\
\end{array}$ & $\begin{array}{l}-.1099 \\
(.1832) \\
\end{array}$ & $\begin{array}{l}-.2446 \\
(.0589) \\
\end{array}$ & $\begin{array}{l}0.0928 \\
(.1054)\end{array}$ \\
\hline \multicolumn{5}{|c|}{ Conditional variance equation } \\
\hline Constant & $\begin{array}{l}.0118 \\
(.0285)\end{array}$ & $\begin{array}{l}.0698 \\
(.0008)\end{array}$ & $\begin{array}{l}.3198 \\
(.0007)\end{array}$ & $\begin{array}{l}0.0084 \\
(.0092)\end{array}$ \\
\hline $\mathrm{ARCH}(1)$ & $\begin{array}{l}.2084 \\
(.2753) \\
\end{array}$ & $\begin{array}{l}.1539 \\
(.0000)\end{array}$ & $\begin{array}{l}.1331 \\
(.0000)\end{array}$ & $\begin{array}{l}0.4831 \\
(.0000)\end{array}$ \\
\hline GARCH(1) & $\begin{array}{l}.5467 \\
(.0002)\end{array}$ & $\begin{array}{l}.8074 \\
(.0000)\end{array}$ & $\begin{array}{l}.8019 \\
(.0000)\end{array}$ & $\begin{array}{l}0.5769 \\
(.0000)\end{array}$ \\
\hline $\begin{array}{l}\text { Program } \\
\text { Duration }\end{array}$ & $\begin{array}{l}.0139 \\
(.0856) \\
\end{array}$ & $\begin{array}{l}.3818 \\
(.0026) \\
\end{array}$ & $\begin{array}{l}.9608 \\
(.0126) \\
\end{array}$ & $\begin{array}{l}0.2992 \\
(.0011) \\
\end{array}$ \\
\hline \multicolumn{5}{|l|}{ Diagnostics tests } \\
\hline $\begin{array}{l}\text { Log likelihood } \\
\text { Q(10) } \\
\mathrm{Q}^{2}(10)\end{array}$ & $\begin{array}{c}110.7215 \\
6.2051 \\
(.8594) \\
.6088 \\
(.9999) \\
\end{array}$ & $\begin{array}{c}-5021.317 \\
11.313 \\
(.3342) \\
5.4636 \\
(.8581) \\
\end{array}$ & $\begin{array}{c}-6547.869 \\
13.073 \\
(.2221) \\
3.3379 \\
(.9723) \\
\end{array}$ & $\begin{array}{c}-1695.5 \\
6.72 \\
(.7521) \\
3.9129 \\
(.9512) \\
\end{array}$ \\
\hline Sample period & $12 / 19 / 96-2 / 27 / 03$ & $01 / 06 / 92-12 / 27 / 02$ & $01 / 06 / 92-12 / 27 / 02$ & $12 / 19 / 96-1 / 19 / 01$ \\
\hline
\end{tabular}

${ }^{1}$ Numbers in parenthesis indicate $p$ values. 


\section{DAVIDSON INSTITUTE WORKING PAPER SERIES - Most Recent Papers}

The entire Working Paper Series may be downloaded free of charge at: www.wdi.bus.umich.edu

CURRENT AS OF 5/03/04

\begin{tabular}{|c|c|c|}
\hline Publication & Authors & Date \\
\hline $\begin{array}{l}\text { No. 680: IMF-Related Announcements, Fundamentals, and Creditor } \\
\text { Moral Hazard: A Case Study of Indonesia }\end{array}$ & $\begin{array}{l}\text { Ayşe Y. Evrensel and Ali M. } \\
\text { Kutan }\end{array}$ & May 2004 \\
\hline No. 679: Privatization Matters: Bank Efficiency in Transition Countries & $\begin{array}{l}\text { John P. Bonin, Iftekhar Hasan and } \\
\text { Paul Wachtel }\end{array}$ & Apr. 2004 \\
\hline $\begin{array}{l}\text { No. 678: Does Market Liberalisation Reduce Gender Discrimination? } \\
\text { Econometric Evidence from Hungary, 1986-1998 }\end{array}$ & $\begin{array}{l}\text { Dean Jolliffe and Nauro F. } \\
\text { Campos }\end{array}$ & Apr. 2004 \\
\hline $\begin{array}{l}\text { No. 677: Governance and Performance of Microfinance Institutions in } \\
\text { Central And Eastern Europe and the Newly Independent States }\end{array}$ & Valentina Hartarska & Apr. 2004 \\
\hline $\begin{array}{l}\text { No. 676: Equilibrium Exchange Rates in the Transition: The Tradable } \\
\text { Price-Based Real Appreciation and Estimation Uncertainty }\end{array}$ & $\begin{array}{l}\text { Balázs Égert and Kirsten } \\
\text { Lommatzsch }\end{array}$ & Apr. 2004 \\
\hline $\begin{array}{l}\text { No. 675: Productivity growth and the real appreciation of the accession } \\
\text { countries' currencies }\end{array}$ & $\begin{array}{l}\text { Kirsten Lommatzsch and Silke } \\
\text { Tober }\end{array}$ & Apr. 2004 \\
\hline $\begin{array}{l}\text { No. 674: Exchange Rate Policy and Inflation in Acceding Countries: } \\
\text { The Role of Pass-through }\end{array}$ & $\begin{array}{l}\text { Fabrizio Coricelli, Boštjan Jazbec } \\
\text { and Igor Masten }\end{array}$ & Apr. 2004 \\
\hline No. 673: Is Kazakhstan a Market Economy Yet? Getting warmer.... & Sharon Eicher & Apr. 2004 \\
\hline $\begin{array}{l}\text { No. 672: Financial Institutions and The Wealth of Nations: Tales of } \\
\text { Development }\end{array}$ & Jian Tong and Chenggang $\mathrm{Xu}$ & Apr. 2004 \\
\hline $\begin{array}{l}\text { No. 671: Interest Rate Pass-Through in EU Acceding Countries: The } \\
\text { Case of the Czech Republic, Hungary and Poland }\end{array}$ & $\begin{array}{l}\text { Jesús Crespo Cuaresma, Balázs } \\
\text { Égert, and Thomas Reininger }\end{array}$ & Mar. 2004 \\
\hline $\begin{array}{l}\text { No. 670: A minimum of rivalry: evidence from transition economies on } \\
\text { the importance of competition for innovation and growth }\end{array}$ & $\begin{array}{l}\text { Wendy Carlin, Mark Schaffer and } \\
\text { Paul Seabright }\end{array}$ & Mar. 2004 \\
\hline No. 669: Dual Track Liberalization: With and Without Losers & $\begin{array}{l}\text { Jiahua Che and Giovanni } \\
\text { Facchini }\end{array}$ & Mar. 2004 \\
\hline $\begin{array}{l}\text { No. 668: Enterprise Restructuring and Firm Performance: } \\
\text { A Comparison of Rural and Urban Enterprises in Jiangsu Province }\end{array}$ & $\begin{array}{l}\text { Xiao-yuan Dong, Louis } \\
\text { Putterman and Bulent Unel }\end{array}$ & Mar. 2004 \\
\hline $\begin{array}{l}\text { No. 667: A Tale of Two Provinces: The Institutional Environment and } \\
\text { Foreign Ownership in China }\end{array}$ & Yasheng Huang and Wenhua Di & Mar. 2004 \\
\hline $\begin{array}{l}\text { No. 666: Ownership Characteristics and Access to Finance: } \\
\text { Evidence from a Survey of Large Privatised Companies in Hungary } \\
\text { and Poland }\end{array}$ & $\begin{array}{l}\text { Natalia Isachenkova and Tomasz } \\
\text { Mickiewicz }\end{array}$ & Mar. 2004 \\
\hline $\begin{array}{l}\text { No. 665: Testing Creditor Moral Hazard in Sovereign Bond Markets: } \\
\text { A Unified Theoretical Approach and Empirical Evidence }\end{array}$ & $\begin{array}{l}\text { Ayşe Y. Evrensel and Ali M. } \\
\text { Kutan }\end{array}$ & Mar. 2004 \\
\hline $\begin{array}{l}\text { No. 664: Assessing Equilibrium Exchange Rates in CEE Acceding } \\
\text { Countries: Can We Have DEER with BEER without FEER? }\end{array}$ & Balázs Égert & Feb. 2004 \\
\hline $\begin{array}{l}\text { No. 663: Modelling stock returns in the G-7 and in selected CEE } \\
\text { economies: A non-linear GARCH approach }\end{array}$ & Balázs Égert and Yosra Koubaa & Feb. 2004 \\
\hline $\begin{array}{l}\text { No. 662: Institutional Change and Product Composition: Does the Initial } \\
\text { Quality of Institutions Matter? }\end{array}$ & $\begin{array}{l}\text { Johannes Moenius and Daniel } \\
\text { Berkowitz }\end{array}$ & Feb. 2004 \\
\hline No. 661: Dual track liberalization: With and without losers & $\begin{array}{l}\text { Jiahua Che and Giovanni } \\
\text { Facchini }\end{array}$ & Feb. 2004 \\
\hline $\begin{array}{l}\text { No. 660: Who Is in Favor of Enlargement? Determinants of Support for } \\
\text { EU Membership in the Candidate Countries' Referenda }\end{array}$ & Orla Doyle and Jan Fidrmuc & Feb. 2004 \\
\hline $\begin{array}{l}\text { No. 659: Creditor Moral Hazard in Equity Markets: } \\
\text { A Theoretical Framework and Evidence from Indonesia and Korea }\end{array}$ & $\begin{array}{l}\text { Ayşe Y. Evrensel and Ali M. } \\
\text { Kutan }\end{array}$ & Feb. 2004 \\
\hline No. 658: Worsening of the Asian Financial Crisis: Who is to Blame? & $\begin{array}{l}\text { Brasukra G. Sudjana and Ali M. } \\
\text { Kutan }\end{array}$ & Feb. 2004 \\
\hline $\begin{array}{l}\text { No. 657: European Integration, Productivity Growth and Real } \\
\text { Convergence }\end{array}$ & Taner M. Yigit and Ali M. Kutan & Feb. 2004 \\
\hline $\begin{array}{l}\text { No. 656: The Impact of News, Oil Prices, and Global Market } \\
\text { Developments on Russian Financial Markets }\end{array}$ & Bernd Hayo and Ali M. Kutan & Feb. 2004 \\
\hline No. 655: Politics and Economic Reform in Malaysia & Bryan K. Ritchie & Feb. 2004 \\
\hline
\end{tabular}

